Our Nature (2008)6: 52-57

\title{
Study on Heavy Metal Resistant Bacteria in Guheswori Sewage Treatment Plant
}

\author{
A. Rajbanshi \\ Central Department of Microbiology \\ Tribhuvan University, Kirtipur, Kathmandu, Nepal
}

Received: 19.10.2008, Accepted: 09.12.2008

\begin{abstract}
Removal of heavy metals from wastewater needs advance chemical technology and is more expensive too. The cheaper alternative for this is the bioremediation using heavy metals resistant microorganisms. In this study, 10 heavy metal resistant bacteria were isolated from oxidation ditch of wastewater treatment plant of Bagmati Area Sewerage Project. These include chromium resistant Staphylococcus spp, Escherichia coli, Klebsiella spp; cadmium resistant Acinetobacter spp, Flavobacterium spp, Citrobacter spp; nickel resistant Staphylococcus spp, Bacillus spp; copper resistant Pseudomonas spp; and cobalt resistant Methylobacterium spp. All the isolates showed high resistance to heavy metals with Minimum Inhibitor Concentration (MIC) for heavy metals ranging from $150 \mu \mathrm{g} / \mathrm{ml}$ to $500 \mu \mathrm{g} / \mathrm{ml}$. Six resistant isolates showed multiple tolerance to heavy metals. All the 10 isolates also showed antibiotic resistance of which $10 \%$ were resistant to single antibiotic and $90 \%$ were multi-antibiotic resistant. Heavy metal tolerance test showed maximum microbial tolerance to chromium and minimum tolerance to nickel in mixed liquor sample of oxidation ditch.
\end{abstract}

Key words: Heavy metal resistant bacteria, multiple tolerance, antibiotic resistance, Guheswori Sewage Treatment Plant

\section{Introduction}

Raw wastewater contains significant concentration of heavy metals that are not degraded by the conventional process of wastewater treatment. The main source of heavy metals is the industrial activities such as metal processing, mining and electroplating, tanning, carpet washing and dyeing. Presence of high concentration of toxic heavy metals in wastewater directly leads to both contamination of receiving water bodies and deleterious impact on aquatic life (Moten and Rehman, 1998). Use of such polluted water for consumption and other purposes can bring severe problems to human health. At higher concentration, heavy metals form toxic complex compounds in the cell that are too dangerous for any biological functions.

Among the microorganisms, bacteria, yeast and protozoa are generally the first category to be exposed to heavy metals present in the environment. Microorganisms have acquired a variety of mechanisms for adaptation to the presence of toxic heavy metals. Among the various adaptation mechanisms, metal sorption, mineralization, uptake and accumulation, extracellular precipitation and enzymatic oxidation or reduction to a less toxic form, and efflux of heavy metals from the cell has been reported (Mergeay, 1991; Hughes and Poole, 1991; Nies, 1992; Urrutia and 
A. Rajbhansi / Our Nature (2008) 6: 52-57

Beveridge, 1993; Joshi-Tope and Francis, 1995).

The heavy metal resistant microorganisms have significant role in wastewater treatment system. The detoxifying ability of these resistant microorganisms can be manipulated for bioremediation of heavy metals in wastewater. Effluents having heavy metals can be treated with these microorganisms by the processes like biosorption, bioaccumulation and bioprecipitation. This study aimed to isolate and identify heavy metal resistant bacteria from Guheshwori Wastewater Treatment Plant situated at the bank of Bagmati River near Guheshwori temple.

\section{Materials and methods Sample collection}

The sampling area was the wastewater treatment plant at Guheshwori constructed by high-powered committee for implementation and monitoring of the Bagmati Area Sewerage Construction / Rehabilitation Project (BASP). The sampling site was the oxidation ditch of the treatment plant. It is the aeration tank where biological treatment of wastewater takes place.

Samples were collected in sterile plastic bottles from the surface of oxidation ditch. A total of eight samples were taken for the study.

\section{Isolation and identification of heavy metal resistant bacteria}

For the selective isolation of heavy metals resistant bacteria, heavy metals incorporated media were used. Basal media nutrient agar (NA) incorporated with heavy metals like $\mathrm{Cd}^{2+}, \mathrm{Ni}^{2+}, \mathrm{Co}^{2+}, \mathrm{Cu}^{2+}$, and $\mathrm{Cr}^{6+}$ were prepared separately. The concentration of each heavy metal was maintained at 100 $\mu \mathrm{g} / \mathrm{ml}$ of the medium. The wastewater sample from oxidation ditch was directly streaked on these media and incubated at $25^{\circ} \mathrm{C}$ for $24-48 \mathrm{~h}$. After the incubation period the plates were observed for any kind of growth on the media. The isolated and distinct colonies on these selective media were subcultured repeatedly on the same media for purification. The pure culture was identified on the basis of their morphology and biochemical characters.

\section{Determination of Minimum Inhibitory Concentration (MIC)}

MIC of the heavy metal resistant bacterial isolates grown on heavy metals incorporated media, against respective heavy metal was determined by gradually increasing the concentration of the heavy metal, $10 \mu \mathrm{g} / \mathrm{ml}$ each time on NA plate until the strains failed to give colonies on the plate. The starting concentration used was $100 \mu \mathrm{g} / \mathrm{ml}$. The culture growing on the last concentration was transferred to the higher concentration by streaking on the plate. MIC was noted when the isolates failed to grow on plates even after 10 days of incubation (Shakoori et al., 1998).

\section{Determination of co-resistance to other heavy metals}

Various bacterial isolates resistant to one heavy metal were tested for their resistance to the rest of the heavy metals chosen for this study. The starting concentration of heavy metals in this test was $50 \mu \mathrm{g} / \mathrm{ml}$, which was gradually increased $10 \mu \mathrm{g} / \mathrm{ml}$ each time until MIC was achieved.

Determination of antibiotic sensitivity and resistance pattern 


\section{A. Rajbhansi / Our Nature (2008) 6: 52-57}

Antibiotic sensitivity and resistance of the isolated heavy metal resistant isolates were assayed according to the Kirby-Bauer disc diffusion method given by Bauer et al. (1996) (Mackey and McCartney, 1996). After incubation, the organisms were classified as sensitive or resistant to an antibiotic according to the diameter of inhibition zone given in standard antibiotic disc chart.

Determination of microbial tolerance of mixed liquor of the oxidation ditch to different heavy metals

Tolerance of microorganisms of oxidation ditch to heavy metals was determined by pour plating the oxidation ditch sample into PCA (Plate count agar) media containing increasing concentration of heavy metals. The initial concentration of heavy metals in this test was taken as $50 \mu \mathrm{g} / \mathrm{ml}$ of the media. After each pour plating procedure, the plates were incubated at $30^{\circ} \mathrm{C}$ for $24-48$ $\mathrm{h}$ and the total numbers of microbial colonies were counted in each plate. The concentration of heavy metals in PCA media was increased until the complete inhibition in the growth.

\section{Results \\ Isolation and identification of heavy metals resistant bacteria}

\section{Antibiotic sensitivity of heavy metals resistant isolates}

All the isolates were resistant to antibiotics of which cobalt resistant Methylobacterium sp. was found to be single antibiotic resistant while the rest of the isolates were found to be multi-antibiotic resistant while the rest of the isolates were found to be multi-antibiotic resistant (Table 3, Figure 2).
Altogether ten heavy metal resistant bacteria were isolated from the oxidation ditch of Guheswori Treatment Plant. All the isolates showed high resistance to heavy metals with MIC for heavy metals ranging from $150 \mu \mathrm{g} / \mathrm{ml}$ to $500 \mu \mathrm{g} / \mathrm{ml}$ (Table 1). All the heavy metal resistant bacteria were tested for their co-resistance to other heavy metals. Among the tested organisms, copper resistant Pseudomonas sp., nickel resistant Staphylococcus sp. and Bacillus sp., cadmium resistant Acinetobacter sp. and Flavobacterium sp. and chromium resistant Staphylococcus sp. showed multiple-tolerance to heavy metals (Table 2).

\section{Microbial tolerance to heavy metals}

The tolerance test indicated that among five experimented heavy metals, maximum tolerance was shown to chromium showing the growth of microorganisms up to $500 \mu \mathrm{g} / \mathrm{ml}$ and minimum tolerance to nickel showing no growth above $200 \mu \mathrm{g} / \mathrm{ml}$. The microbial tolerance at each concentration of heavy metal was depicted by the microbial load on PCA plate expressed as C.F.U/ml. The microbial load decreased with the increase in concentration of heavy metals indicating toxic effect of the heavy metals on the growth of microorganisms (Figure 1).

The Guheswori Treatment Plant of BASP collects all the domestic as well as industrial wastewater from Gokarna, Bouddha, and Jorpati areas. The wastewater coming from domestic and industrial sources is the appropriate environment where the microorganisms can develop resistance to heavy metals and antibiotics. The presence of small amount of antibiotics and heavy metals in the wastewater induce the emergence of 
A. Rajbhansi / Our Nature (2008) 6: 52-57

Table 1. Heavy metals resistant bacteria.

\begin{tabular}{|l|l|l|}
\hline Bacteria & Resistant to & MIC \\
\hline Staphylococcus sp. & Chromium & $500 \mu \mathrm{g} / \mathrm{ml}$ \\
Escherichia coli & Chromium & $200 \mu \mathrm{g} / \mathrm{ml}$ \\
Klebsiella sp. & Chromium & $150 \mu \mathrm{g} / \mathrm{ml}$ \\
Citrobacter sp. & Cadmium & $220 \mu \mathrm{g} / \mathrm{ml}$ \\
Acinetobacter sp. & Cadmium & $150 \mu \mathrm{g} / \mathrm{ml}$ \\
Flavobacterium sp. & Cadmium & $300 \mu \mathrm{g} / \mathrm{ml}$ \\
Pseudomonas sp. & Copper & $300 \mu \mathrm{g} / \mathrm{ml}$ \\
Staphylococcus sp. & Nickel & $150 \mu \mathrm{g} / \mathrm{ml}$ \\
Bacillus sp. & Nickel & $200 \mu \mathrm{g} / \mathrm{ml}$ \\
Methylobacterium sp. & Cobalt & $250 \mu \mathrm{g} / \mathrm{ml}$ \\
\hline
\end{tabular}

Table 2. Co-resistance to other heavy metals

\begin{tabular}{|l|l|l|}
\hline Organisms & Co-resistance to & MIC \\
\hline $\mathrm{Cu}^{2+}$-resistant Pseudomonas sp. & Cobalt & $150 \mu \mathrm{g} / \mathrm{ml}$ \\
$\mathrm{Ni}^{2+}$-resistant Staphylococcus sp. & Cadmium & $120 \mu \mathrm{g} / \mathrm{ml}$ \\
$\mathrm{Ni}^{2+}$-resistant Bacillus sp. & Cobalt & $150 \mu \mathrm{g} / \mathrm{ml}$ \\
$\mathrm{Cd}^{2+}$-resistant Acinetobacter sp. & Cobalt & $110 \mu \mathrm{g} / \mathrm{ml}$ \\
& Copper & $200 \mu \mathrm{g} / \mathrm{ml}$ \\
$\mathrm{Cd}^{+2}$-resistant Flavobacterium sp. & Cobalt & $180 \mu \mathrm{g} / \mathrm{ml}$ \\
& Copper & $220 \mu \mathrm{g} / \mathrm{ml}$ \\
$\mathrm{Cr}^{6+}$ resistant Staphylococcus sp. & Cobalt & $200 \mu \mathrm{g} / \mathrm{ml}$ \\
& Cobalt & $150 \mu \mathrm{g} / \mathrm{ml}$ \\
& Cadmium Nickel & $140 \mu \mathrm{g} / \mathrm{ml}$ \\
\hline
\end{tabular}

Table:3 Antibiotic sensitivity of heavy metals resistant bacteria

\begin{tabular}{|c|c|c|c|}
\hline $\mathbf{S N}$ & Organisms & Sensitive to & Resistant to \\
\hline 1 & $\mathrm{Cr}^{6+}$ resistant Staphylococcus sp. & $\begin{array}{l}\text { Ciprofloxacin, Vancomycin, } \\
\text { Methicillin }\end{array}$ & $\begin{array}{l}\text { Penicillin, } \\
\text { Erythromycin, }\end{array}$ \\
\hline 2 & $\mathrm{Cr}^{6+}$ resistant E. coli & Gentamycin, Choramphenicol. & $\begin{array}{l}\text { Ampicillin, Cotrimoxazole, } \\
\text { Ciprofloxacin, tetracycline. }\end{array}$ \\
\hline 3 & $\mathrm{Cr}^{6+}$ resistant Klebsiella $\mathrm{sp}$. & Gentamycin, Cotrimoxazole & $\begin{array}{l}\text { Tetracycline, Ciprofloxacin, } \\
\text { Chloramphenicol, } \\
\text { Ampicillin. }\end{array}$ \\
\hline 4 & $\mathrm{Ni}^{2+}$ resistant Staphylococcus sp. & $\begin{array}{l}\text { Tetracycline, Ciprofloxacin, } \\
\text { Vancomycin. }\end{array}$ & Penicillin, Erythromycin. \\
\hline 5 & $\mathrm{Cd}^{+2}$ resistant Citrobacter $\mathrm{sp}$. & $\begin{array}{l}\text { Ampicillin, Gentamycin, } \\
\text { Ciprofloxacin. }\end{array}$ & $\begin{array}{l}\text { Tetracycline, } \\
\text { Choramphenicol. }\end{array}$ \\
\hline 6 & $\mathrm{Cd}^{+2}$ resistant Acinobacter $\mathrm{sp}$. & $\begin{array}{l}\text { Chloramphenicol, Cotrimoxazole, } \\
\text { Gentamycin, Ciprofloxacin }\end{array}$ & Tetracycline, Ampicillin \\
\hline 7 & $\mathrm{Cd}^{+2}$ resistant Flavobacterium sp. & $\begin{array}{l}\text { Chloramphenicol, Gentamycin, } \\
\text { Ciprofloxacin. }\end{array}$ & $\begin{array}{l}\text { Tetracycline, Ampicillin, } \\
\text { Co-trimoxazole. }\end{array}$ \\
\hline 8 & $\begin{array}{lll}\mathrm{Co}^{+2} & \text { resistant } & \text { Methylobacterium } \\
\text { sp. } & & \end{array}$ & $\begin{array}{l}\text { Tetracycline, Ciprofloxacin, } \\
\text { Cotrimoxazol, Ampicillin, } \\
\text { Gentamycin. }\end{array}$ & Chloramphenicol \\
\hline
\end{tabular}


A. Rajbhansi / Our Nature (2008) 6: 52-57

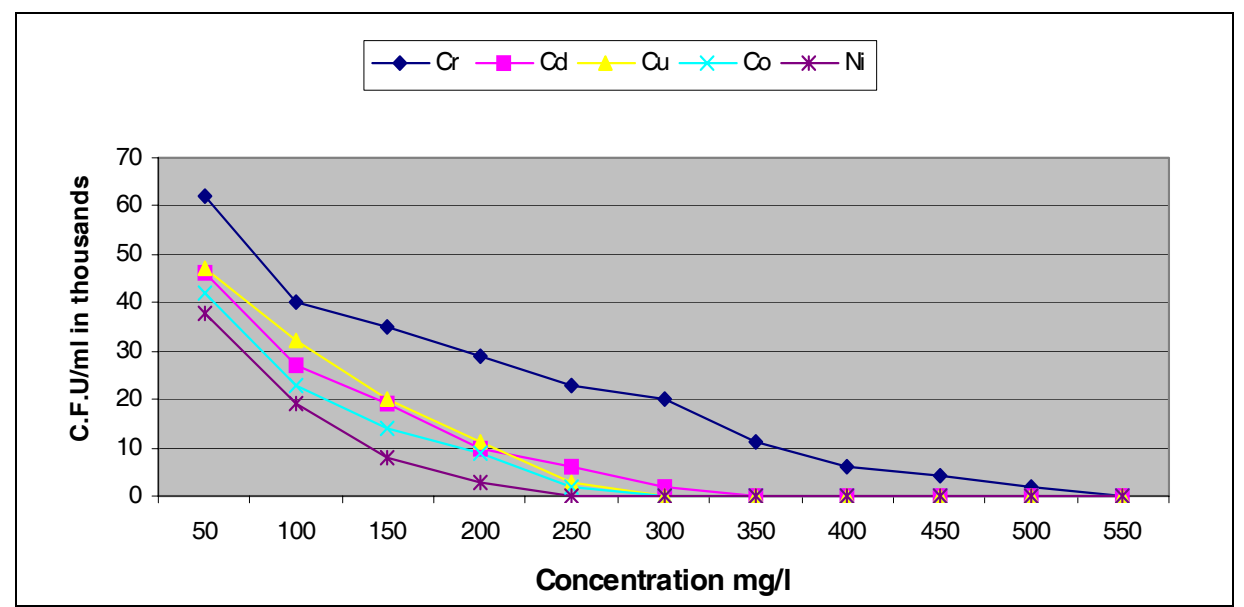

Figure 1. Microbial tolerance to heavy metals

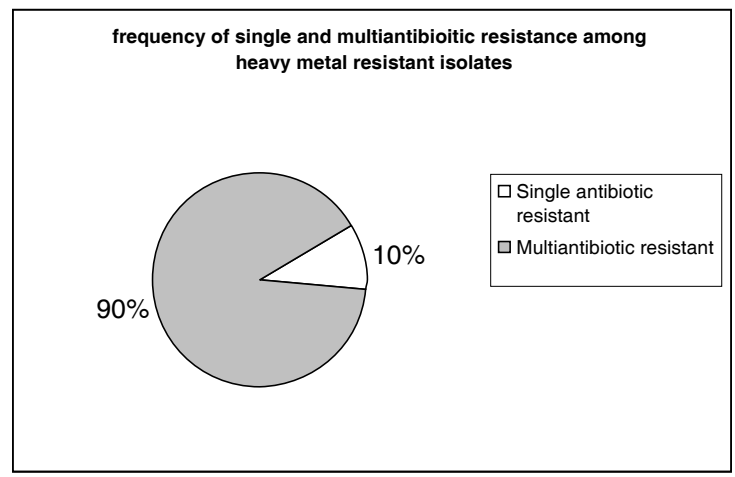

Figure 2. Antibiotic resistance of heavy metal resistant isolates

antibiotic resistant and heavy metal resistant microorganisms. Most of the isolates in the present study showed multiple tolerances to both heavy metals and antibiotics. The microbial resistance to heavy metal is attributed to a variety of detoxifying mechanism developed by resistant microorganisms such as complexation by exopolysaccharides, binding with bacterial cell envelopes, metal reduction, metal efflux etc. These mechanisms are sometime encoded in plasmid genes facilitating the transfer of toxic metal resistance from one cell to another (Silver, 1996). Filali et al. (1999) studied wastewater bacteria isolates 
A. Rajbhansi / Our Nature (2008) 6: 52-57

Psuedomonas aeroginosa, Klebsiella pneumoniae, Proteus mirabilis and Staphylococcus resistant to heavy metals and antibiotics. Similarly, Sharma et al. (2000) isolated highly cadmium resistant Klebsiella that was found to precipitate significant amount of CdS. The heavy metal resistant organism could be a potential agent for bioremediation of heavy metals pollution. Multiple tolerances occur only to toxic compounds that have similar mechanisms underlying their toxicity. Since heavy metals are all similar in their toxic mechanism, multiple tolerances are common phenomena among heavy metal resistant bacteria. In wastewater, there are some substances that have the potential to select for antibiotic resistance even though they are not antibiotics themselves. Heavy metals and biocides are two of them. The exposure to heavy metals or biocides results in the selection of bacterial strain also able to resist antibiotics. This happens because genes encoding heavy metals and biocides are located together with antibiotic resistance genes or alternatively because bacteria can have unspecific mechanism of resistance common to different substances including heavy metals, biocides and antibiotics (Dalsgarrd and Guardbassi, 2002). It is therefore, likely that selective pressure by one such compound indirectly selects for the whole set of resistances.

\section{Acknowledgements}

I would like to acknowledge Bagmati Area Sewerage Construction / Rehabilitation project for giving the permission to conduct the study. I also like to thank laboratory staff of the project for their co-operation.

\section{References}

Dalsgarrd, A. and L. Guardbassi 2002. Occurrence and fate of antibiotics resistant bacteria in sewage. Danish, EPA Environment Project No. 722

Filali, B.K., J. Taoufik, Y. Zeroual, F.A.Z. Dzairi, M. Talbi, and M. Blaghen 1999. Waste water bacterial isolates resistant to heavy metals and antibiotics. Current Microbiology 41: 151-156.

Hughes, M.N. and R.K. Poole 1991. Metal speciation and microbial growth, the hard and soft facts. Journal of General Microbiology 137: 725-734.

Joshi-Tope, G. and A.J. Francis 1995. Mechanisms of biodegradation of metal-citrate complexes by Pseudomonas fluroescens. Journal of Bacteriology 177: 1989-1993.

Mackey and McCartney 1996. Practical Medical Microbiology, 14the Edition.

Mergeay, M. 1991. Towards an understanding of the genetics of bacterial metal resistance. Trends in Biotechnology 9: 17-24.

Moten, A.M. and A. Rehman 1998. Study on heavy trace metal ions in industrial waste effluents in Pakistan. Enviromental-expert.com, article-909

Nies, D.H. 1992. Resistance to cadmium, cobalt, zinc and nickel in microbes. Plasmid 27: 17-28.

Shakoori, A.R., K.S. Zaidi, and R. Haq 1998. Cadmium resistant Enterobacter clacae and Klebsiella sp isolated from industrial effluents and their possible role in cadmium detoxification. World Journal of Microbiology and biotechnology 15: 249-254.

Sharma, K.P., A. Frenkel, and L.D. Balkwill 2000. A new Klebsiella planticola strain (cd-1) grows anaerobically at high cadmium concentrations and precipitates cadmium sulphide. Applied and Environmental Microbiology 66: 3083-3087.

Silver, S. 1996. Bacterial resistances to toxic metal ions-a review. Gene 179: 9-19.

Urrutia, M.M. and T.J. Beveridge 1993. Remobilization of heavy metals retained as oxyhydroxides or silicates by Bacillus subtilis cells. Applied and Environmental Microbiology 59: 4323-4329. 